\title{
WOKÓŁ DWUJĘZYCZNOŚCI
}

Rafat Zarębski*

\author{
PAMIĘTNIKI JAKO ŹRÓDŁO WIEDZY \\ O KSZTALTOWANIU SIĘ KOMPETENCJI LEKSYKALNEJ \\ (NA PRZYKŁADZIE XVII-WIECZNYCH \\ LES ANECDOTES DE POLOGNE... F. P. DALAIRACA)
}

\begin{abstract}
Słowa kluczowe: bilingwizm francusko-polski, kompetencja, leksyka, pamiętnik, polszczyzna XVII wieku

Streszczenie. W artykule podjęto próbę opisu kompetencji leksykalnej w XVII-wiecznym, francuskojęzycznym pamiętniku F. P. Dalairaca Les anecdotes de Pologne.... Autor, który był poddanym Ludwika XIV, przebywał na dworze króla Jana III Sobieskiego. W diariuszu dokumentującym wydarzenia związane z wyprawą wojenną w 1683 roku zamieścił bogaty polski materiał leksykalny. Na podstawie obserwacji słownictwa specjalistycznego i ogólnego, które zostało wplecione w tekst francuski, można sądzić, że autor posiadał zaawansowaną kompetencję językową w zakresie języka polskiego, był więc osobą dwujęzyczną. Poddany ekscerpcji pamiętnik stanowi ciekawe źródło do badań charakterystycznych dla mowy biblingwalnej zachowań językowych, które były konsekwencją dawnych kontaktów językowych.
\end{abstract}

Do opisu kształtowania się bilingwizmu indywidualnego najlepiej służą analizy konkretnych przypadków, które można prowadzić na dwu płaszczyznach: synchronicznej (współcześnie występujące przypadki dwu- czy wielojęzyczności) i diachronicznej (ślady dawnej dwujęzyczności). Ponadto każda z tych płaszczyzn - oczywiście w zależności od dostępności źródeł, materiałów i okoliczności zewnętrznych - może być ujmowana statycznie (w odniesieniu do konkretnego stadium dwujęzyczności) bądź dynamicznie (w odniesieniu do przebiegu kształtowania się zjawiska). Pierwsza miałaby zatem charakter punktowy, druga - pro-

*rafal.zarebski@uni.lodz.pl, Uniwersytet Łódzki, Wydział Filologiczny, Instytut Filologii Polskiej i Logopedii, Zakład Historii Języka Polskiego, ul. Pomorska 171/173, 90-236 Łódź, ORCID: 0000-0003-1918-2169. 
cesualny. Śledzenie przebiegu stawania się danej jednostki dwujęzyczną w perspektywie synchronicznej stanowi wdzięczne zadanie badawcze. Procedura ta umożliwia ogląd doskonalenia się poszczególnych kompetencji komunikacyjnych (lingwistycznych, socjolingwistycznych i pragmalingwistycznych) w zakresie opanowywanego języka (ESOKJ 2003, s. 20-23) niejako na bieżąco, często in statu nascendi. Możemy wówczas nie tylko dokonywać ewaluacji postępów w nauce osoby uczącej się, ale przede wszystkim wskazywać i diagnozować czynniki determinujące proces uczenia (sytuacja rodzinna i zawodowa uczącego się, sposób, w jaki opanowuje on język, cel nauki itd.), a także te zjawiska, struktury gramatyczne czy zachowania językowe (chodziłoby tu zwłaszcza o problemy związane z transferem negatywnym z języka ojczystego, pierwszego ${ }^{1}$ ), które sprawiają mu szczególne problemy i próbować im zaradzić (zob. Miodunka 2003, s. 90-95).

Zgoła inaczej przedstawiają się badania bilingwizmu indywidualnego w perspektywie historycznej, kiedy badacz współczesny właściwie może tylko rekonstruować stan bycia dwujęzycznym (diachroniczne ujęcie statyczne) czy proces stawania się dwujęzycznym (diachroniczne ujęcie dynamiczne) na podstawie dostępnych zabytków. Dobrym źródłem do tego typu badań są różnego rodzaju teksty użytkowe, czyli takie, które, najogólniej rzecz biorąc, przeciwstawiają się tekstom literackim. Teksty nieliterackie, użytkowe to byty niejako „przenoszone z uniwersum mowy w obręb literatury” (Dobrzyńska 2001, s. 309-310), np. opowiadanie, list, wyznanie, modlitwa, pamiętnik, wspomnienia, a także dwuczy wielojęzyczne rozmówki, słowniczki, a nawet partie dialogowe w tekstach artystycznych itd., które Maria Wojtak określa jako „wypowiedzi, które funkcjonują prymarnie poza literaturą, służąc określonym celom praktycznym" (Wojtak 2004-2005, s. 157). Spośród zarysowanego tu uniwersum piśmiennictwa użytkowego do badań bilingwizmu najlepiej nadaje się literatura dokumentu osobistego (Czermińska za: Ligara 2014b, s. 163) z właściwymi sobie gatunkami. W ich obrębie bowiem w przypadku autorów dwujęzycznych szczególnie łatwo dochodzi do kontaktów międzyjęzykowych. Jak pisze Bronisława Ligara, „(...) gatunki te nie tylko przystają na mowę dwujęzyczną, ale nawet sankcjonują ją tak, że staje się ona czymś w rodzaju ich cechy genologicznej” (Ligara 2014b, s. 164).

Opis bilingwizmu diachronicznego obarczony jest zwykle pewną dozą niepewności, zwłaszcza w sytuacjach, kiedy nie dysponujemy świadectwami bezpośrednimi, czyli wyrażonymi explicite wypowiedziami na temat prób opanowywania drugiego języka, czy pewnymi informacjami obecnymi w biografii danej osoby itd., dokumentującymi zjawisko. Dużo łatwiej - oczywiście tylko w przypadku, kiedy mamy dostęp do odpowiednich tekstów - opisywać interesujące nas zagadnienie w odniesieniu do osób, najczęściej znanych z pewnych istotnych do-

${ }^{1} \mathrm{Na}$ temat terminologii zob. Lipińska 2003, s. 41-78 oraz polemiczne artykuły W. Cockiewicza (2013) i W. Miodunki (2013). 
konań, które spowodowały, że zapisały się one w historii, zasłużonych z jakichś względów, o których wiadomo, że były dwujęzyczne. Liczne, choć często rozproszone źródła, przynoszą na ogół sporo informacji, na podstawie których możemy wnioskować, w jaki sposób przebiegał sposób akwizycji danego języka oraz jak i w jakich sytuacjach ten język był używany. W odniesieniu do mniej znanych osób bilingwalnych, na których temat nie dochowały się dokumenty, jakie mogłyby posłużyć do opisu stopnia ich dwujęzyczności, zdani jesteśmy wyłącznie na pozostawione przez te jednostki konkretne przykłady poświadczające użycie języków w kontakcie. Te zaś najłatwiej znaleźć we wspomnianej już literaturze dokumentu osobistego, która wykazuje szczególną predyspozycję do odzwierciedlania mowy osób dwujęzycznych, innymi słowy - mowy dwujęzycznej (Ligara 2014a, s. 151).

Trzeba też podkreślić, iż - inaczej niż ma to miejsce w odniesieniu do przypadków dwujęzyczności współczesnej, synchronicznej - ślady używania różnych języków w tym samym dawnym tekście nie umożliwiają opisu wszystkich kompetencji językowych, a tylko niektóre $\mathrm{z}$ nich (w najmniejszym stopniu fonetyczno-fonologiczną). $Z$ faktem tym wiąże się zagadnienie dotyczące stopnia zaawansowania kompetencji językowej i komunikacyjnej w zakresie obu kodów. Według jednych bilingwizm oznacza biegłą znajomością języka, właściwie na tym samy poziomie jak w przypadku języka ojczystego (pierwszego) (Lipińska 2003, s. 115), według zaś innych już ograniczona sprawność w obrębie jednego z języków może być przejawem dwujęzyczności (Cockiewicz 2013, s. 211; Walczak 2014, s. 182-183). Jej pierwszy typ, kształtowany od najmłodszych lat danego indywiduum, jest określany mianem dwujęzyczności zrównoważonej, natomiast drugi związany z późniejszym, dokonującym się po 16., 17. roku życia, a więc w życiu dorosłym, nabywaniem języka drugiego - dominującej (Hamers, Blanc 1983, s. 24-25, 27; za: Ligara 2010, s. 145-146; Ligara 1987, 24). Warto zaznaczyć, że, jak pisze B. Ligara, ,przedstawione dwa rodzaje bilingwizmu są oczywiście stanem idealnym, gdyż w rzeczywistości występują najczęściej formy pośrednie z nachyleniem do jednego lub drugiego typu" (1987, s. 25).

Diachroniczne podejście do interesującej mnie kwestii, związane z niekompletnością danych, wymusza i uzasadnia przyjęcie szerokiej perspektywy, zgodnie z którą przejawem bilingwizmu może być już częściowe opanowanie języka drugiego, zgodnie z rozumieniem zjawiska zaproponowanym przez I. Kurcz, która przez dwujęzyczność (wielojęzyczność) rozumie „fakt posługiwania się przez daną osobę dwoma (lub więcej niż dwoma) językami, przy czym nie określa się bliżej stopnia znajomości tych języków" (Kurcz 1992, s. 180). Na potrzeby naszych rozważań warto tę definicję rozszerzyć o aspekt funkcjonalny, obecny w pracach B. Ligary, a przyjęty za specjalistami szwajcarskimi ${ }^{2}$. Funkcjonalne

${ }^{2}$ Należą do nich m.in. François Grosjean, Georges Lüdi i Bernard Py (zob. Ligara 2010; 2014a; 2014b). 
ujęcie dwujęzyczności zakłada, że osoba dwujęzyczna, praktykująca regularnie oba języki, potrafi - gdy to możliwe lub konieczne - przechodzić z jednego na drugi w wielu rozmaitych sytuacjach, nawet $\mathrm{z}$ kompetencją znacznie asymetryczną (Ligara 2014a, s. 162; por. hasło bilinguisme w: GD).

Badania dwujęzyczności polsko-francuskiej w aspekcie diachronicznym, a zatem takiej, której śladów poszukujemy w dawnych tekstach, nie mają w Polsce długiej tradycji ${ }^{3}$. Właściwie można by tu wyznaczyć dwa etapy: wcześniejszy, kiedy badaczy interesowała kwestia wpływów francuskich w tekstach polskich, przy czym nie posługiwali się oni terminem bilingwizmu, a relacje pomiędzy oboma językami rozpatrywali w kontekście kontaktów językowych i normy językowej (Doroszewski 1966; Urbańczyk 1967), oraz późniejszy, zapoczątkowany badaniami B. Ligary $(1987 ; 2010 ; 2014 a ; 2014 b)$ nad galicyzmami w listach Zygmunta Krasińskiego, przez tę badaczkę rozwijany i stosowany do chwili obecnej, związany z wykorzystaniem metodologii i aparatu badawczego z zakresu glottodydaktyki i bilingwizmu.

Postawa metodologiczna B. Ligary charakteryzuje się tym, że autorka, odrzuciwszy perspektywę normatywną, zastosowaną do opisu wpływów francuskich w języku Adama Mickiewicza przez Witolda Doroszewskiego, na bilingwizm diachroniczny patrzy z perspektywy antropologii lingwistycznej. Zgodnie z założeniami lingwistyki kulturowej (zwłaszcza w ujęciu André Jacoba) akcentuje się fakt, że uobecniający się w tekstach język osoby dwujęzycznej stanowi reakcję na życie w świecie dwóch kodów i odzwierciedla to doświadczenie. Badaczka podkreśla, że dla przyjętego przez nią paradygmatu priorytet stanowi poszukiwanie genezy mechanizmów powodujących dane zachowanie językowe. Tak wyznaczony kierunek badań podporządkowuje analizę strukturalną „operacji językowych”, wynikających z pozostawania obu kodów w kontakcie właśnie wyjaśnieniu ich przyczyn (Ligara 2010, s. 142-144) . Do zachowań tych należą trzy typy wykładników transkodowych, spotykanych w tekstach odzwierciedlających mowę dwujęzyczną: 1) code switching // przełączanie kodów // przemienność kodów, 2) code mixing // (z)mieszanie kodów, 3) interferencje i zapożyczenia (Ligara 2010, s. 149-166; 2014a, s. 150; 2014b).

Badania Ligary opierają się na analizie mowy dwujęzycznej wybitnych jednostek (Mickiewicza, Krasińskiego), dla których polszczyzna była językiem pierwszym. Trzeba natomiast zauważyć, że zupełnie sporadycznie obserwacji

\footnotetext{
${ }^{3}$ Dość istotnym kontekstem dla badań dawnych tekstów dwujęzycznych może być zjawisko makaronizowania, odnoszone przede wszystkim do średniopolskich tekstów polsko-łacińskich. Powołując się na ustalenia S. Skwarczyńskiej i Z. Klemensiewicza, pisze o tym B. Ligara (2014a, s. $152-153)$.

${ }^{4}$ Tak zaprojektowana optyka badań prowadzi do neutralizacji opozycji diachronia - synchronia: „Strukturalistyczna opozycja diachronii (ewolucji języka) i synchronii (stanu języka) traci tutaj rację bytu na rzecz syntezy genezy i struktury (...)” (Ligara 2010, s. 143-144).
} 
podlegały przypadki odwrotne, w których polski był językiem drugim. Próbę takiego opisu - choć bez kontekstu glottodydaktycznego - przynosi artykuł Stanisława Urbańczyka na temat polszczyzny we francuskich listach królowej Marysieńki (zob. Urbańczyk 1967).

Moim zamiarem jest przyjrzenie się tylko jednemu z aspektów dwujęzyczności, a mianowicie kompetencji leksykalnej ujmowanej statycznie (rozmiar źródeł, aczkolwiek duży, to jednak niewystarczający, by można było mówić o zjawisku w sposób procesualny, dynamiczny) właśnie w tekście, którego autor poznawał język polski jako obcy. Wykorzystam w tym celu napisany po francusku przez François-Paulina Dalairaca ${ }^{5}$ pamiętnik pt. Les anecdotes de Pologne ou memoires secrets du regne de Jean Sobieski III. du Nom (Les anecdotes...), który po raz pierwszy został wydany w dwóch tomach w Amsterdamie w roku $1699^{6}$. W opanowywaniu języka obcego - jak podkreślają badacze - leksyka zajmuje miejsce nadrzędne, ponieważ jej nieznajomość bywa główną przyczyną blokady komunikacji (Ostromęcka-Frączak 2013, s. 24) ${ }^{7}$. Przypomniany zabytek stwarza również okazję do badań dwujęzyczności autora w kontekście istotnych z perspektywy lingwistyki antropologicznej i tekstologii zachowań językowych, nazywanych przez B. Ligarę wykładnikami transkodowymi. Sądzę jednak, że takie ujęcie powinno być poprzedzone opisem niższych pięter analizy glottodydaktycznej, a mianowicie poszczególnych kompetencji językowych autora. Wykorzystane źródło takie obserwacje umożliwia.

Badania zapisanej mowy dwujęzycznej powinny odnosić się do językowej biografii autora - nadawcy (Ligara 2014a, s. 162). W przypadku jednostek mało znanych, które w historii nie zapisały się jakimiś szczególnymi czynami i o których życiu ze względu na brak dokumentów wiemy niewiele, jest to zadanie trudne, czasem nawet karkołomne. O autorze Les anecdotes... wiadomo tyle, że urodził się we Francji, gdzie żył jako poddany Ludwika XIV, był powiernikiem króla Jana III Sobieskiego i jego żony Marysieńki, doręczycielem listów królewskich spod Wiednia i Parkanów, jeńcem w niewoli tureckiej i członkiem licznych misji dyplomatycznych (Folkierski 1925). Warstwa fabularna pamiętnika obejmuje okres związany z wojną polsko-turecką u schyłku XVII w., w szczególności zaś z wydarzeniami rozgrywającymi się wokół bitew pod Wiedniem i Parkanami, które miały miejsce w roku 1683. Dzieło jest wartościowe nie tylko pod względem historycznym, ale także obyczajowym. Na jego kartach znajdujemy liczne, niekiedy dość obszerne opisy życia oraz obyczajów panujących w dawnej Polsce i krajach sąsiednich, w tym także w Turcji. Jeśli zaś chodzi o znajomość języka polskiego przez Dalairaca, to nie mamy dokładnych informacji, w jakim zakresie

${ }^{5}$ Inne warianty nazwiska: Dalerac, Dallerac, d'Allayrac, czy spolszczone: Franciszek Paulin Dalerak (zob. Folkierski 1925, s. 5).

${ }^{6}$ Pamiętnik doczekał się kilku wydań (w Paryżu w r. 1700, a w rok później w przekładzie na język holenderski i angielski), co świadczy o jego znacznej popularności (zob. Folkierski 1925, s. 5).

${ }^{7}$ Tam też literatura na ten temat. 
ją posiadał. Z parą królewską i na dworze porozumiewał się zapewne po francusku, jednak musiał mieć znaczne rozeznanie w polszczyźnie, skoro zamieścił w tekście bogaty materiał polski. W słowie wstępnym do pamiętnika autor informuje, że jego znajomość niemieckiego, tureckiego i węgierskiego nie jest na tyle wystarczająca, by materiał leksykalny z tych języków obecny w tekście można było uznać za zapisany całkowicie poprawnie. Natomiast co do znajomości polskiego wypowiada się w sposób następujący: „(...) Quant au Polonois, il (l'auteur - R.Z.) a pris les avis des gens de la Nation, qui l'ont aidé à mettre les noms propres un peu plus correctement que ceux des autres langues, dont il n'a pas tant de connoissance"8. Można zatem sądzić, że Francuz dysponował - prawdopodobnie niepełną - kompetencją w zakresie języka polskiego, czemu zresztą trudno się dziwić, skoro przez kilka lat przebywał wśród Polaków.

Charakter wydarzeń wspomnianych w pamiętniku w znacznej mierze determinuje zasób odnotowanego słownictwa w aspekcie jakościowym. Mieści się ono w ściśle wyznaczonych rodzajem opisu kręgach tematycznych, spośród których w sposób najbogatszy zostało zilustrowane pole wojskowości. Należą tu przede wszystkim nazwy osób pełniących w wojsku rozmaite funkcje, w tym również wyrazy o zasięgu ogólnym, ale w znaczeniu specjalistycznym, np.

chłopiec 'mężczyzna, żołnierz, towarzysz; giermek, pachołek, paź, posłaniec, sługa' (SXVII/XVIII): „Voilà ce qu'on apelle les combats des klopechés, dont il faut expliquer le mot, pour ne rien laisser à desirer au lecteur curieux. On nome ici un petit garçon *klopietz (...); (*Ce mot s'écrit chlopiec, qu'il faut prononcer comme je le marque dans le corps de l'ouvrage)"9 (I, 51),

chorąży 'żołnierz noszący chorągiew; urzędnik, któremu powierzona była chorągiew ziemska' (SXVII/XVIII): „Quant au korongy, ou porte-Etendart de la Couronne, sa charge n'a aucune fonction dans l'armée, mais seulement dans l'arriere-ban, qu'on apelle ici pospolite russienne, ce qui veut dire la noblesse marchante" ${ }^{10}$ (I, 19),

hajduk 'służący w wojsku węgierskim' (SXVII/XVIII): „Hayduques, sont des fantassins, \& le mot est hongrois orginairement"11 $(\mathrm{I}, 6)$,

hetman 'naczelny wódz wojsk zaciężnych lub jego zastępca', też 'dowódca wojsk niepolskich, zwłaszcza Kozaków zaporoskich; ataman’ (SXVII/XVIII): „Le grand general

\footnotetext{
${ }^{8}$ Strona nienumerowana, wstęp do tomu I. Cytaty francuskie podaję w oryginalnej pisowni XVII-wiecznej, przy czym każdorazowo zamieniam długie $s(()$ na $s$ oraz modernizuję pisownię wielkich i małych liter. W przypadku dłuższych fragmentów zamieszczam własne tłumaczenia: „Co do polszczyzny autor uwzględniał uwagi Polaków, którzy pomagali mu zapisywać nazwy własne nieco poprawniej niż pochodzące z innych języków, których nie miał wystarczającej znajomości”.

${ }^{9}$ Znaczenie wyrazów za SXVII/XVIII i/lub SJPD. „Nazywamy to walką chłopców, przy czym należy wyjaśnić znaczenie słowa, by nie pozostawiać ciekawego czytelnika bez należytego objaśnienia. Małego chłopca określamy też chłopcem. Słowo to zapisujemy chłopiec; trzeba je wymawiać tak, jak zaznaczam w tekście głównym dzieła".

${ }^{10}$ „Co do chorążego to nie ma on żadnej funkcji w wojsku, poza tą w pospolitym ruszeniu, które oznacza marsz szlachecki”.

${ }^{11}$ „Hajducy to żołnierze piechoty, słowo pochodzenia węgierskiego”.
} 
s'apelle en latin supremus dux; en polonois hetman *koronny. Le petit general est nommé en latin dux compestris; en polonois hetman polny"12 (I, 12),

husarz 'żołnierz służący w husarii' (SJPD): „La gendarmerie est encore de deux fortes, *houssars, \& pancernes; (*s'écrit uszarz panczernik)"13 (I, 21),

janczar 'żołnierz piechoty tureckiej utworzonej z wziętych do niewoli chrześcijan, wychowanych przez Turków' (SXVII/XVIII): „Ils ont aussi une espece de dragons armez de mousquets semblables à ceux de l'infanterie appellez de même *yancharz, du nom des yancharz ou janissaires (...)"14 (I, 297),

oboźny 'urzędnik wojskowy zakładający obóz w miejscu wyznaczonym przez wodza' (SXVII/XVIII): „L'obogenik est ce que nous apellons maréchal des logis des armées” (...) $(\mathrm{I}, 19 ; \mathrm{II}, 233)^{15}$,

osiadacz 'ten co osiada, np. osiadacz konny' (SW): „On apelle aussi ces valets d'armes oschadacz, qu'il faut écrire osiadacz, \& le prononcer comme ci-dessus” ${ }^{\prime 16}$ (I, 27),

pacholik 'człowiek niższego stanu a. uboższy szlachcic używany do posług, towarzyszący panu również w czasie wojny, sługa; szeregowy żołnierz’ (SXVII/XVIII): „*On apelle ces volets d'armes les pacolets, \& en polonois pacholik, qu'il faut prononcer comme en françois)" ${ }^{\prime \prime}$ (I, 27),

pancernik 'rycerz ubrany w pancerz, osłonięty zbroją' (SXVII/XVIII): „Le second espece de gandarmerie est celle des pancernes, un peu moins considerables que les houssars, mais beaucoup au dessus de toute autre cavalerie. Leur nom vient de leur armûre, qui est une chemise de maille, apellé en polonois *pancernik"18 (I, 30), por. husarz (I, 21),

strażnik 'dowódca straży w wojsku', 'wysoki urzędnik państwowy mający obowiązek pilnowania i obrony granic przed napadami nieprzyjacielskimi, szczególnie tatarskimi; później urząd honorowy', 'człowiek należący do straży, trzymający straż; wartownik' (SXVII/XVIII): „Cet officier s'apelle le *stragenik”19 (I, 18),

petyhorzec, petyhorski hist. 'w dawnej Litwie: żołnierz jazdy lżejszej lub husarii (odpowiednik towarzysza pancernego w Koronie)' (SJPD) zob. kopia,

towarzysz ' $\mathrm{w}$ dawnym wojsku polskim: szlachcic zaciągający się do chorągwi husarskiej lub pancernej z własnym pocztem' (SJPD): ,(...) les generaux du nom de *touariche, c'est-à-dire camarade ou compagnon" (I, 21; II, 228 $)^{20}$.

${ }^{12}$ „Najważniejszy dowódca to po łacinie supremus dux, po polsku hetman koronny. Podległy mu generał jest nazywany po łacinie dux compestris, po polsku - hetman polny".

${ }^{13}$ „Żandarmeria ma jeszcze dwie grupy: husarzy i pancerników (pisze się uszarz, panczernik)”.

${ }^{14}$ „Mają też rodzaj żołnierzy uzbrojonych w muszkiety podobne do tych piechoty, nazywanych janczarami, od imienia janczar (...)”.

${ }^{15}$ „Oboźny to ten, którego nazywamy wachmistrzem”.

${ }^{16}$ „Nazywa się tych wojskowych pomocników osiadaczami, co trzeba pisać osiadacz i wymawiać jak wyżej”.

${ }^{17}$ „Tych pomocników nazywa się pacholikami; po polsku pacholik, co trzeba wymawiać jak po francusku".

${ }^{18}$ „Drugi rodzaj żandarmerii to pancernicy, nieco mniej ważni niż husarze, ale znacznie przewyższający resztę wojsk konnych. Ich nazwa pochodzi od nazwy zbroi - pancernej koszuli. Nazywani są po polsku pancernikami”.

${ }_{19}$ „Ten oficer nazywa się strażnikiem”.

${ }^{20}$ „(...) generałowie zwani towarzyszami, to znaczy towarzyszem lub kolega". 
Obok wplecionych w tekst francuski osobowych rzeczowników i urzeczownikowionych przymiotników w analizowanym pamiętniku występują również nazwy broni, np.

buława 'krótka laska zakończona ozdobną gałką; w Polsce symbol władzy, zwłaszcza wojskowej'; 'broń obuchowa, maczuga, pałka' (SXVII/XVIII): „Les generaux ont encore un baton de commandement, donné par le roy avec la charge, de même qu'aux maréchaux de France. C'est une masse d'armes fort court, finissant par un bout en grosse pomme, ou d'argent, ou de vermeil doré, qu'on enrichit quelquefois de pierreries. Ce bâton s'apelle le *boulaf; (*s'écrit bulawa)"21 (I, 12-13),

dzida 'dawna broń składająca się ze strzałkowatego ostrza osadzonego na długim drzewcu, rodzaj lekkiej włóczni; kopia, lanca, pika, spisa’ (SJPD) zob. kopia,

kopia 'lanca' (SJPD): „(...) les lances (...) celles des houssars s'apellent *kopies, les autres *gides; le premier mot vient sans doute du latin copia, qui signifie troupe; le second est un mot du pays, qui est en usage aussi parmi les Turcs, de même que cette especes de lances; (*s'écrit kopia, s'écrit dzida, qu'il faut prononcer gida)" (I, 31-32) ${ }^{22}$,

obuch 'rodzaj broni, siekiera na długim toporzysku' (SXVII/XVIII): „de certaines haches; les polonois ils apellent *obuk (*s'écrit obuk)"23 (I, 49),

symboli i znaków wojskowych, np.

buńczuk 'drzewce z kulą i poprzeczką, z zawieszonymi na niej ogonami końskimi, jako oznaka władzy wojskowej używana przez Turków, Tatarów, Kozaków oraz hetmanów polskich' (SJPD): „(...) une grosse pomme ou boule de quelque étoffe riche; ce qui s'apelle le bontchouk en polonois" (I, 12, 125)

oraz związane z organizacją i sposobem działania polskiego wojska, a także wojsk państw sąsiadujących z I Rzeczpospolitą, np.

horda 'u ludów tureckich: wojsko, obóz wojskowy, kwatera chana; federacja szczepów tureckich pod dowództwem chana' (SJPD): „(...) il vint en effet quelque *horde de Tartares à Camienieck; ( ${ }^{*}$ Horda est le nom que les Tartares donnent à leurs brides, compagnies, ou regiments)" 25 (II, 250),

komput 'zbiór, liczba', 'poczet wojska' (SXVII/XVIII): „(...) mais comme ce nombre n'est jamais complet, l'armée est tantôt plus, tantôt moins forte. Selon les éforts que fait

${ }^{21}$ „Generałowie mają jeszcze laskę władzy, wręczoną wraz ze stanowiskiem przez króla, tak jak marszałkowie we Francji. To ciężka, krótka laska zakończona wielkim jabłkiem, srebrnym lub pozłacanym srebrem, którą czasem zdobią szlachetne kamienie. Ta laska zwie się buława (pisze się bulawa)".

${ }^{22}$, ,...) włócznie (...) te husarzy nazywają się kopiami, pozostałe - dzidami. Pierwsze słowo pochodzi bez wątpienia z łaciny - copia, co oznacza grupę, wojsko; drugie jest słowem rodzimym, używanym również przez Turków, także na ten rodzaj włóczni (pisze się kopia, pisze się $d z i d a$, co trzeba wymawiać gida)".

${ }^{23}$ „rodzaj siekiery, po polsku nazywanej obuchem (pisze się obuk)”.

${ }^{24}$, „(..) duże jabłko lub kula z bogatej tkaniny, co nazywa się buńczukiem po polsku”.

${ }^{25}$ „W końcu do Kamieńca przybyło kilka hord Tatarów (horda to nazwa, którą Tatarzy nadają swoim grupom, kompaniom lub regimentom)". 
la République au besoin; sans jamais pourtant parvenir à ce nombre de quarante-huit mille hommes, fixé par l'état de la guerre apellé en polonois *kompout; (s'écrit komport) ${ }^{n 26}(\mathrm{I}, 11)$

pospolite ruszenie 'powszechna wyprawa na wojnę szlachty posiadającej ziemię' (SXVII/XVIII) zob. choraży,

pułk 'samodzielna jednostka organizacyjna w różnych rodzajach wojsk (np. w piechocie, artylerii, lotnictwie), składa się ze sztabu, 3-5 batalionów (eskadr, dyonów) i pododdziałów zaopatrzenia' (SJPD): „La cour fut rencontrée en arrivant à Yasloviets; par une brigade ou poulc de cavalerie commandée par le castelan de Kelms" (I, 267; II, 277) ${ }^{27}$.

Oprócz specjalistycznej leksyki wojskowej Dalairac używa słownictwa z innych kręgów tematycznych, a także o zasięgu bardziej ogólnym. Do pola nazw urzędowo-administracyjnych można zaliczyć rzeczowniki, np.

hospodar 'tytuł panującego; osoba będąca nosicielem tego tytułu' (SVXVII/XVIII): „Dans cette vûë le roy de Pologne pratiqua le hospodar ou prince des Valaques, pour l'engager à lui païer le tribut établi par les sultans"28 (II, 153),

kuchmistrz 'mistrz sztuki kucharskiej, kierownik kuchni'; 'przełożony nad kuchnią, dawny urzędnik nadworny' (SJPD): „C'est le Coq-mistre, ou le Maître d'Hôtel de la Couronne" (I, 150 ; I, 264) ${ }^{29}$,

pisarz 'w urzędach miejskich, gminach miejskich, przedsiębiorstwach handlowych, kancelariach królewskich i wojskowych itp.: urzędnik pełniący funkcję sekretarza, zajmujący się sprawami administracyjnymi, finansowymi itp.' (SJPD); „Le * pissar revient à la charge de commissaire general" ${ }^{30}(\mathrm{I}, 19)$,

podstarosta 'pomocnik, zastępca starosty'; 'w majątkach ziemskich w dawnej Polsce: pomocnik ekonoma, karbowy’ (SJPD): „Je gagnay ensuite Reetchouf château du prince Lubomirski, dont le podstarosta ou capitain me donna caleche qui me conduisit à Yaroslave" 31 (I, 364).

Odrębną grupę stanowią wyrazy związane z życiem i codziennym funkcjonowaniem człowieka, np.

dom 'budynek mieszkalny' (SXVII/XVIII) zob. kamienica,

gospoda 'mieszkanie przeznaczone na krótki pobyt; kwatera; stancja'; 'dom zajezdny, zajazd; karczma' (SXVII/XVIII) zob. kamienica,

${ }^{26}$, „....) lecz że ta liczba nigdy nie jest kompletna, wojsko raz jest silniejsze, raz słabsze. Mimo wysiłków państwa nigdy jednak liczba ta nie osiąga pułapu 48 tysięcy ludzi, wyznaczonego na wypadek wojny; liczba ta nazywa się po polsku komput (pisze się komport)".

${ }^{27}$ „Sąd odbył się po przybyciu do Jazłowca ze względu na oddział lub pułk kawalerii skazany przez kasztelana chełmskiego".

${ }^{28}$ „W tym ujęciu król polski zabiegał, aby hospodar lub książę wołoski płacił mu trybut ustanowiony przez sułtanów".

${ }^{29}$ „To jest kuchmistrz lub szef koronnej służby restauracyjnej”.

${ }^{30}$ „Pisarz od stanowiska komisarza generalnego".

${ }^{31}$ „Zdobyłem później zamek Rzeszów księcia Lubomirskiego, którego starosta lub kapitan dał mi powóz, którym zajechałem do Jarosławia". 
kamienica ‘dom zbudowany z kamieni lub cegieł, dom murowany' (SXVII/XVIII): ,,(..) en sorte qu'une maison de maçonnerie, pierre ou brique, a un nom particulier pour la distinguer du mot general de maison, lequel convient à toutes, soit de bois, soit d'autre matiere; ce nom particulier est kaminitsa, qu'ils expliquent en latin par celuy de lapidea, au lieu que le terme generique, est domo, ou gospodi"'32 (II, 261),

kamień 'odłamek, kawałek bryły skalnej' (SXVII/XVIII): „Kamin en polonois signifiant pierre ou roche" 33 (II, 261),

karczma 'szynk na wsi, gospoda; dawniej również dom zajezdny, austeria, oberża' (SJPD): „(...) où sont les moulins, avec un méchant cartchema dans le chemin" ${ }^{34}$ (II, 235),

kasza 'potrawa z ziaren zbóż' (SXVII/XVIII): „(...) les Polonois (...) soûpiroient après leur bière, leurs choux, leur *cacha, sans quoy ils se croyent pas pouvoir vivre"35 $(I, 207)$,

kotara 'zasłona zwykle z grubej tkaniny; portiera' (SJPD): „Il y a des cotars; en polonois kotara" (I, 39 ; I, 54) ${ }^{36}$,

kożuch 'futro, skóra zwierzęcia o długim puszystym owłosieniu, najczęściej barania lub owcza; odzienie wierzchnie z takiej skóry' (SJPD): „(...) ce qu'on apelloit publiquement en Pologne, (...) les *cojouques, c'est-à-dire les fourrures ${ }^{37}$ (II, 241),

pieniadze 'środek płatniczy’ (SJPD): „Enfin le roy (...) répondait à tous les points de l'accusation de pignonze avec une force admirable (...)"38 (II, 337),

spośród których pewna tylko część należy do słownictwa podstawowego, np. dom, pieniadze, podczas gdy reszta - jeśli na zjawisko patrzeć z perspektywy glottodydaktycznej - mieściłaby się w obrębie zasobu znamiennego dla zaawansowanego poziomu przyswajania języka. W tym zbiorze trzeba by też umieścić leksykę z pola świata przyrody charakterystycznego dla polskiej szerokości geograficznej, np.

ryśs 'zwierzę drapieżne z rodziny kotów' (SXVII/XVIII): „Il y a une espece de loups cerviers, appellez rich en Pologne, dont la fourrure est fort riche aussi, tres-fine, \& fort belle (...)"39 (II, 357-358).

${ }^{32}$, „(...) więc dom murowany, z kamienia lub cegły, posiada odrębną nazwę, żeby go odróżnić od słowa dom w znaczeniu ogólnym, oznaczającym każdy rodzaj domu, czy to z drewna, czy z innego materiału; ta odrębna nazwa to kamienica, którą na łacinę tłumaczy się lapidea, zamiast ogólnego terminu dom lub gospoda".

${ }^{33}$ „Kamień oznacza po polsku kamień lub głaz”.

${ }^{34}$ „,(..) gdzie są młyny i nieprzyjemna karczma po drodze”.

${ }^{35}$ „(...) Polacy (...) wzdychają za swoim piwem, swoją kaszą; kasza, bez której nie potrafiliby żyć".

${ }^{36}$ „Są dwa rodzaje kotar; po polsku kotara”.

37 „co w Polsce nazywano (...) kożuchem, czyli futrem”.

${ }^{38}$ „W końcu król odpowiedział z siłą godną podziwu na wszystkie punkty oskarżenia o pieniądze".

${ }^{39}$ „Istnieje gatunek lupus cervarius (łac.), nazywany w Polsce rysiem; jego futro jest bardzo grube, wytworne i piękne". 
Zasób leksykalny XVII-wiecznego autora można scharakteryzować nie tylko na płaszczyźnie słownictwa minimum - jako słownictwo zaawansowane, ale także, co nie pozostaje bez znaczenia dla diachronicznego ujęcia mowy bilingwalnej, z perspektywy lingwistyki antropologicznej. Szczególnie ważne wydają się tu odautorskie sygnały wskazujące na przynależność Dalairaca do konkretnej wspólnoty językowo-narodowej. Pisarz na ogół podkreśla, że na opisywaną rzeczywistość patrzy z perspektywy obcego, czemu służą stwierdzenia typu to, co my (Francuzi) nazywamy..., Polacy nazywaja ..., ich piwo, ich kapusta, ich kasza (Polaków), np. ce que nous apellons maréchal des logis des armées (zob. oboźny), les polonois ils apellent... (zob. obuch), leur bière, leurs choux, leur cacha (zob. kasza). Oznaką przełamywania dystansu natomiast mogą być formy użycia francuskiego zaimka osobowego on w znaczeniu 'my', w których pamiętnikarz próbuje identyfikować się z Polakami, np. on nomme ici..., on apelle ici... Są one o tyle ważne, że sytuują autora po stronie obserwowanej nacji, a zatem już w strefie obcych. My inkluzywne, choć w tym kontekście może być też interpretowane jako figura retoryczna, ma też spore znaczenie dla oceny stopnia zaawansowania w procesie przyswajania polszczyzny i jej roli jako składnika zapisanej mowy dwujęzycznej.

Na podstawie analizy polszczyzny w interesującym nas tekście wiele można by też powiedzieć, gdyby na nią spojrzeć w kontekście wykładników transkodowych, tak ważnych - jak tego w swoich badaniach dowodzi B. Ligara (2010; 2014a; 2014b) - dla opisu zjawiska bilingwizmu. Zagadnienia te pozostają - jak zasygnalizowano we wstępnych partiach naszego studium - poza sferą opisu, choć tylko pobieżny ogląd materiału pokazuje, że w analizowanym teście mamy do czynienia ze wszystkimi typami zachowań językowych, o jakich mówi badaczka, które były realizowane w różnorodny sposób. Polszczyzna Dalairaca została, co prawda, wpleciona w tekst francuski, ale uobecnia się za pośrednictwem różnych dróg. Raz są to zwyczajne objaśnienia słownikowe funkcjonujące na prawach niemalże definicji leksykograficznych, raz - objaśnienia o charakterze encyklopedycznym, raz - uwagi marginalne, w których zawarto informacje z zakresu pisowni, wymowy czy właściwości gramatycznych danego wyrazu (zob. Zarębski 2018a; 2018b), wreszcie - jednostki polskie dopasowane (bądź nie) do tekstu francuskiego, np. après quoi il retourna à la porte de la kotar qu'il entre'ouvrit en passant la tête, pour remercier le roy $(\mathrm{I}, 154)$ na zasadzie przemienności i zmieszania kodów. Autorowi nieobce są także różnorodne interferencje językowe, np. kalki. Pełny opis tych zależności nie jest tu możliwy z tego względu, że poza przedmiotem zainteresowania pozostawiam przejawy kompetencji graficzno-fonetycznej i gramatycznej autora. Dopiero całościowe spojrzenie na materiał polski uobecniający się w pamiętniku mogłoby posłużyć do pełnej analizy mowy dwujęzycznej, zapisanej w zabytku w kontekście transkodowości. Jednak już na tym etapie badań dobrze widać, jak dwujęzyczny tekst, stanowiący zamkniętą komunikacyjną 
całość językową, może odzwierciedlać obecną w umyśle osoby dwujęzycznej nie sumę dwóch kompetencji jednojęzycznych, ale zorganizowaną, spójną strukturę, „w której dwa systemy językowe współzamieszkują" (zob. Ligara 2014a, s. 156).

Warto tu zwrócić uwagę na jeszcze jedną cechę charakterystyczną polskiej leksyki obecnej w dawnym pamiętniku. Otóż znaczna jej część wiąże się z różnicami kulturowymi pomiędzy niegdysiejszą rzeczywistością języka polskiego i francuskiego. Wiele z użytych przez autora polskich leksemów i związków wyrazowych nie posiada tożsamych ekwiwalentów tłumaczeniowych we francuszczyźnie. Chodzi tu o takie jednostki, które wiążą się z „wyrażaniem pojęć właściwych danej kulturze i zbiorowemu doświadczeniu ludzi mówiących danym językiem" (Ostromęcka-Frączak 2013) i powinny być rozpatrywane jako etnologizmy, historyzmy i/lub kulturyzmy. Stanowią one ważny element kompetencji leksykalnej i kulturowej. W świetle tak obfitego materiału z tego zakresu dwujęzyczność Dalairaca wydaje się mocno zaawansowana.

Z oglądu materiału leksykalnego obecnego w tekście płynie jeszcze jeden, najważniejszy chyba wniosek. Skoro autor, po pierwsze, zamieścił w pamiętniku tak liczną grupę wyrazów specjalistycznych (choć - jak mieliśmy okazję zobaczyć - nie pominął także leksyki ogólnej), co prawda, niejako predystynowanych do pojawienia się w zabytku o takiej tematyce, a po drugie, spróbował się utożsamić z użytkownikami polszczyzny, to musiał posiadać zaawansowaną kompetencję językową. Na korzyść tej hipotezy przemawiają też inne fakty. Jeśli przypomnimy liczne komentarze językowe Dalairaca na temat właściwości pisownianych, fonetycznych i gramatycznych polszczyzny, np. il fait au vocatif chlopeché car la langue Polonois se décline comme Latin (I, 51), jeśli zwrócimy uwagę na językoznawcze zacięcie autora, które widać choćby w następującym fragmencie: *Ils s'apellent Pototski du nom de Potok à la manière polonoise, dont la langue fait un participie comme la latin, à la place de notre de par exemple nous disons l'evêque cracovien; le ski étant la finale du participe ${ }^{40}$ (II, 255), jeśli przywołamy dowody dużej świadomości Francuza w zakresie kompetencji pragmalingwistycznej, np. (...) en Pologne, où l'on s'anime par un *cry, semblable presque au nôtre, en disant, frape, tuë $\ddot{e}^{41}(\mathrm{I}, 22)$, to ujrzymy autora jako osobę dwujęzyczną, która wcale nieźle musiała opanować XVII-wieczną polszczyznę nie tylko o zasięgu ogólnym (choć na ten temat wnioskujemy niejako pośrednio), ale również zdolną operować pewnym słownictwem należącym do złóż specjalistycznej leksyki nie tylko rodzimej, ale i wówczas zapożyczonej, np. horda, janczar. Dalsze badania nad wspomnieniami Dalairaca mogą tę hipotezę wzmocnić, a także przyczynić się do odpowiedzi na pytanie, jaki w istocie typ bilingwizmu był mu właściwy.

${ }^{40}$ „*Nazywają się Potoccy od nazwy Potok na sposób polski; w tym języku tworzy się imiesłów tak jak w łacinie, w miejscu naszego de, na przykład mówimy biskup krakowski; ski jest końcówką imiesłowu".

${ }^{41}$ „W Polsce, gdzie nawołujemy się *okrzykiem, nieco podobnym do naszego, uderz, zabij”. 


\section{BIBLIOGRAFIA}

Cockiewicz W., 2013, Jak uporzadkować terminologiczny chaos w glottodydaktyce i po co? „LingVaria", nr 1 (15), s. 201-213.

Dobrzyńska T., 2001, Tekst, w: J. Bartmiński (red.), Współczesny język polski, Lublin, s. 293-314.

Doroszewski W., 1966, O galicyzmach w listach Mickiewicza, w: W. Doroszewski, Wśród stów, wrażeń i myśli. Refleksje o języku polskim, Warszawa, s. 467-474.

ESOKJ: Europejski system opisu ksztatcenia językowego: uczenie się, nauczanie, ocenianie, 2003, Council of Europe: D. Coste, B. North, J. Sheils, J. Trim, trad. W. Martyniuk, Warszawa.

Folkierski W., 1925, Kłopoty francuskiego autora XVII wieku z polszczyzna, Kraków.

GD: Dubois J., Giacomo M., Guespin L., Marcellesi Ch., Marcellesi J.-B., Mével J.-P., 2007, Grand dictionnaire. Linguistique \& sciences du langage, Paris.

Hamers J. F., Blanc M., 1983, Bilingualité et bilinguisme, Bruxelles.

Kurcz I., 1992, Język a psychologia, Warszawa.

Les anecdotes...: Les anecdotes de Pologne ou memoires secrets du regne de Jeans Sobieski III. Du nom, t. 1-2, Amsterdam 1699, wydał Henry Desbordes (autor F. P. Dalairac).

Ligara B., 1987, Galicyzmy leksykalne w listach Zygmunta Krasińskiego na tle wpływów francuskich w polszczyźnie XIX wieku (studium bilingwizmu polsko-francuskiego), Kraków.

Ligara B., 2010, Bilingwizm polsko-francuski Adama Mickiewicza. W stronę antropologii lingwistycznej, „LingVaria”, nr 2 (10), s. 141-170.

Ligara B., 2014a, Bilingwizm w tekście zapisany. Część I. Status lingwistyczny. Paradygmaty badawcze, ,LingVaria”, nr 1 (17), s. 149-167.

Ligara B., 2014b, Bilingwizm w tekście zapisany. Część II. Wyktadniki transkodowe. Gatunki, „LingVaria", nr 2 (18), s. 139-174.

Lipińska E., 2003, Język ojczysty, język obcy, język drugi. Wstęp do badań dwujęzyczności, Kraków.

Miodunka W., 2003, Bilingwizm polsko-portugalski w Brazylii. W stronę lingwistyki humanistycznej, Kraków.

Miodunka W., 2013, O definiowaniu języków ojczystego i obcego oraz o „,terminologicznym chaosie” w glottodydaktyce - polemicznie, „LingVaria”, nr 2 (16), s. 275-283.

Ostromęcka-Frączak B., 2013, Rola leksyki w ksztaltowaniu kompetencji komunikacyjnej cudzoziemców (na materiale języka polskiego i słoweńskiego), „Acta Universitatis Lodziensis. Kształcenie Polonistyczne Cudzoziemców”, nr 20, E. Pałuszyńska, I. Dembowska-Wosik (red.), s. 23-31.

SJPD: Stownik języka polskiego, red. W. Doroszewski, https://sjp.pwn.pl/doroszewski/lista [05.03.2018].

SXVII/XVIII: Elektroniczny stownik języka polskiego XVII $i$ XVIII wieku, https://sxvii.pl [05.03.2018].

Urbańczyk S., 1967, Polszczyzna Marysieńki Sobieskiej, „Język Polski”, t. XLVII, s. 168-173.

Walczak B., 2014, Trzy refleksje o dwujęzyczności, „Poznańskie Spotkania Językoznawcze”, nr 27, s. $181-191$.

Wojtak M., 2004-2005, Genologia tekstów użytkowych, „Postscriptum”, nr 2, 1, s. 156-171.

Zarębski R., 2018a, Z dziejów językowych kontaktów polsko-francuskich. Polszczyzna w XVII-wiecznym pamiętniku F. P. Dalairaca pt. Les anecdotes de Pologne ou memoires secrets du regne de Jean Sobieski III du nom, „Poradnik Językowy”, z. 2, s. 14-27.

Zarębski R., 2018b, Les anciens textes usuels comme la source de connaissance sur la formation des compétences linguistiques en polonais ( $\mathrm{w} \mathrm{druku).}$ 
Rafat Zarębski

\section{DIARIES AS A SOURCE OF KNOWLEDGE ABOUT THE DEVELOPMENT OF LEXICAL COMPETENCE AS EXEMPLIFIED BY THE 17TH CENTURY LES ANECDOTES DE POLOGNE... BY F. P. DALAIRAC}

Keywords: French-Polish bilingualism, competence, lexis, diary, Polish language of $17^{\text {th }}$ century

Summary. The author analyzes the lexical competence of F.P. Dalairac as reflected in the diary Les anecdotes de Pologne... written in French in the $17^{\text {th }}$ century. Dalairac, who was the subject of king John III Sobieski, had written a diary that documented the events of the military expedition in 1683. He included in his diary rich Polish lexical material which was interspersed with the French text throughout the book. The study of this general and specialist vocabulary proves that the author of the diary possessed advanced knowledge of the Polish language. Dalairac was bilingual in French and Polish. His diary is the interesting source for the research on bilingual competence resulting from language influences at the time. 